\title{
Kesulitan Memahami Konseptual Dan Prosedural Kesetimbangan Kimia Pada Siswa SMA Di Kota Palangka Raya
}

\author{
Seliwati \\ SMA Negeri 5 Palangka Raya, Kalimantan Tengah, Indonesia \\ Email: seliwati74@gmail.com
}

\begin{abstract}
Abstrak. Tujuan penelitian ini adalah untuk mendeskripsikan kesulitan siswa kelas XI MIPA SMA Negeri dan Swasta di Kota Palangka Raya dalam memahami konseptual dan prosedural kesetimbangan kimia Tahun Ajaran 2017/2018. Ilmu kimia memiliki beberapa karakteristik yang khas, antara lain : 1) sebagian besar materi kimia bersifat abstrak yaitu konsep yang termasuk dalam tataran mikroskopis ; 2) ilmu kimia merupakan penyederhanaan dari yang sebenarnya; 3) materi kimia tidak hanya sekedar memecahkan soal-soal secara matematis melainkan harus mempelajari deskripsi kimia, peristilahan khusus dan aturan-aturan kimia. Karakteristik ini dapat dikelompokkan menjadi dua, yaitu matematis dan non matematis. Pengetahuan matematis dapat dijelaskan dengan rumus dan perhitungan kimia yang terletak pada level pengetahuan prosedural dan pengetahuan non matematis dapat dijelaskan dengan menggunakan level pengetahuan konseptual. Konsep kesetimbangan kimia tergolong sulit untuk dipelajari. Kesulitan tersebut terutama disebabkan konsep kesetimbangan kimia yang merupakan penjelasan dari keadaan mikroskopis dan konsep yang berkembang seara berurutan. Konsep kimia yang merupakan konsep abstrak akan dapat dipahami oleh siswa apabila siswa mampu menciptakan gambaran batin yang benar. Siswa diharapkan memahami pengetahuan konseptual dan prosedural tersebut. Hasil tes siswa tentang pemahaman konseptual dan prosedural kesetimbangan kimia diharapkan mencapai ketuntasan $100 \%$.
\end{abstract}

Kata kunci : kesulitan, konseptual, prosedural, kesetimbangan kimia

\section{PENDAHULUAN}

Menurut Permendikbud No. 69 Tahun 2013, dalam kurikulum 2013 terdapat empat kompetensi inti (KI) yang dituntut dimiliki oleh siswa SMA/ MA dan salah satunya yaitu pada KI ke- 3, siswa dituntut untuk memahami, menerapkan dan menganalisis pengetahuan faktual, konseptual dan prosedural berdasarkan rasa ingin tahunya tentang ilmu pengetahuan, teknologi, seni, budaya, dan humaniora dengan wawasan kemanusiaan, kebangsaan, kenegaraan, dan peradaban terkait penyebab fenomena dan kejadian, serta menerapkan pengetahuan prosedural pada bidang kajian yang spesifik sesuai dengan bakat dan minatnya untuk memecahkan masalah (Kemendikbud, 2013, hlm. 7).

Middlecamp \& Kean (1985) menyatakan bahwa ilmu kimia memiliki beberapa karakteristik yang khas, antara lain : 1) sebagian besar materi kimia bersifat abstrak yaitu konsep yang termasuk dalam tataran mikroskopis (seperti atom, molekul, elektron dan ikatan kimia; 2) ilmu kimia merupakan penyederhanaan dari yang sebenarnya; 3)materi kimia tidak hanya sekedar memecahkan soal-soal secara matematis melainkan harus mempelajari deskripsi kimia, peristilahan khusus dan aturan-aturan kimia. Karakteristik ini dapat dikelompokkan menjadi dua, yaitu matematis dan non matematis. Pengetahuan 
matematis dapat dijelaskan dengan rumus dan perhitungan kimia yang terletak pada level pengetahuan prosedural dan pengetahuan non matematis dapat dijelaskan dengan menggunakan level pengetahuan konseptual. Karakteristik stoikiometri termasuk dalam konsep abstrak dan konkret. Konsep konkret berupa pengetahuan matematis yang berada pada level pengetahuan procedural dan konsep abstrak berupa pengetahuan non matematis yang berada pada level pengetahuan konseptual.

Konsep-konsep dalam ilmu kimia tergolong sulit untuk dipelajari. Kesulitan memahami ilmu kimia terutama disebabkan konsep kimia yang merupakan penjelasan dari keadaan mikroskopis dan konsep yang berkembang seara berurutan. Konsep kimia yang merupakan konsep abstrak akan dapat dipahami oleh siswa apabila siswa mampu menciptakn gambaran batin yang benar. Herron ( 1985) menyatakan bahwa konsep atau materi kimia secara keseluruhan merupakan konsep abstrak yang hanya dapat dipahami dengan baik oleh individu yang telah mencapai tingkat operasi formal sebagaimana teori perkembangan yang dikemukakan Piaget. Menurut Sidauruk (2005) konsep ilmu kimia yang sebagian bersifat abstrak berpotensi terjadi miskonsepsi.

Untuk mengukur ketercapaian kompetensi inti tersebut, maka diperlukan alat evaluasi yang mampu mengukur penguasaan pengetahuan konseptual dan prosedural siswa. Dalam ilmu kimia, pemahaman konsep (konseptual) dan belajar pemecahan masalah (prosedural) sangatlah penting. Untuk memecahkan masalah dengan benar, siswa membutuhkan aplikasi dari pengetahuan konseptual dan prosedural (Cracolice, 2004, hlm. 877). Kimia merupakan mata pelajaran yang tidak sedikit mengandung konsep-konsep yang abstrak (Sirhan, 2007, hlm. 2). Konsep kimia yang merupakan konsep abstrak akan dapat dipahami oleh siswa apabila siswa mampu menciptakan gambaran batin yang benar. Siswa diharapkan memahami pengetahuan konseptual dan prosedural tersebut. Hasil tes siswa tentang pemahaman konseptual dan prosedural kesetimbangan kimia diharapkan mencapai ketuntasan $100 \%$.

Hasil penelitian yang dilakukan oleh Yunitha Andrie (2012) mengungkapkan tentang kesulitan Memahami konsep kesetimbangan kimia pada Siswa Kelas XI IPA SMA Negeri Tahun Ajaran 2011/2012 di kota Palangka Raya menunjukkan bahwa penguasaan siswa dalam memahami: konsep kesetimbangan kimia (Jika nilai kriteria ketuntansan minimal siswa (KKM) adalah 75) maka : (1) Pengaruh perubahan volume terhadap pergeseran kesetimbangan kimia $(46,6)$; (2) Penguasaan konsep siswa dalam konsep kesetimbangan dinamis $(45,65)$; (3) Pengaruh perubahan konsentrasi terhadap pergeseran kesetimbangan $(41,84)$; (4) Pengaruh perubahan suhu terhadap pergeseran kesetimbangan $(14,92)$. Prosentase siswa kesulitan dalam konsep (1) Pengaruh perubahan tekanan terhadap pergesseran kesetimbangan $(85,08 \%)$; (2) Pengaruh perubahan suhu terhadap pergeseran kesetimbangan (64,94 \%); (3) Pengaruh perubahan konsentrasi terhadap pergeseran kesetimbangan $(58,16 \%)$; (4) Penguasaan konsep siswa dalam konsep kesetimbangan dinamis $(54,35 \%)$; (5) Pengaruh perubahan volume terhadap pergeseran kesetimbangan kimia $(53,4 \%)$. Siswa lebih mudah menjawab soal dalam bentuk pernyataan dari pada soal dalam bentuk gambar.

Hasil Ujian Nasional Berbasis Komputer Tahun Pelajaran 2016/21017 untuk mata pelajaran kimia pada SMAN 5 Palangka Raya nilai rata-rata 53,75. Data ini menjelaskan bahwa sebagian besar siswa di sekolah tersebut kesulitan 
memahami mata pelajaran kimia. Berikut adalah hasil Ujian Nasional Berbasis Komputer tahun 2017 ditunjukkan pada gambar 1 berikut :

\begin{tabular}{|c|c|c|c|c|c|c|c|}
\hline \multirow{2}{*}{ NILAI } & \multicolumn{6}{|c|}{ MATA PELAJARAN } & \multirow{2}{*}{$\begin{array}{c}\text { JML. } \\
\text { NIL }\end{array}$} \\
\hline & BIN & ING & MAT & FIS & KIM & BIO & \\
\hline Kategori & $\mathrm{B}$ & $D$ & $\mathrm{D}$ & $\mathrm{D}$ & $\mathrm{D}^{\circ}$ & $\mathrm{D}$ & C \\
\hline Rata-Rata & 78.02 & 52.21 & 37.94 & 50.33 & 53.75 & 53.46 & 221.12 \\
\hline Terendah & 48.00 & 24.00 & 17.50 & 25.00 & 35.00 & 30.00 & 151.00 \\
\hline Tertinggi & 96.00 & 90.00 & 75.00 & 70.00 & 80.00 & 80.00 & 304.00 \\
\hline Std Deviasi & 9.77 & 16.55 & 13.15 & 12.55 & 13.05 & 13.25 & 38.40 \\
\hline
\end{tabular}

Gambar 1. Nilai UNBK SMAN 5 Palangka Raya

Hasil Ujian Nasional Berbasis Komputer yang menyatakan sebagian besar siswa belum memahami ilmu kimia di atas di dukung oleh hasil ulangan harian siswa SMA Negeri 5 Palangka Raya pada materi kesetimbangan kimia seperti pada gambar $2 \mathrm{a}$ dan $2 \mathrm{~b}$.
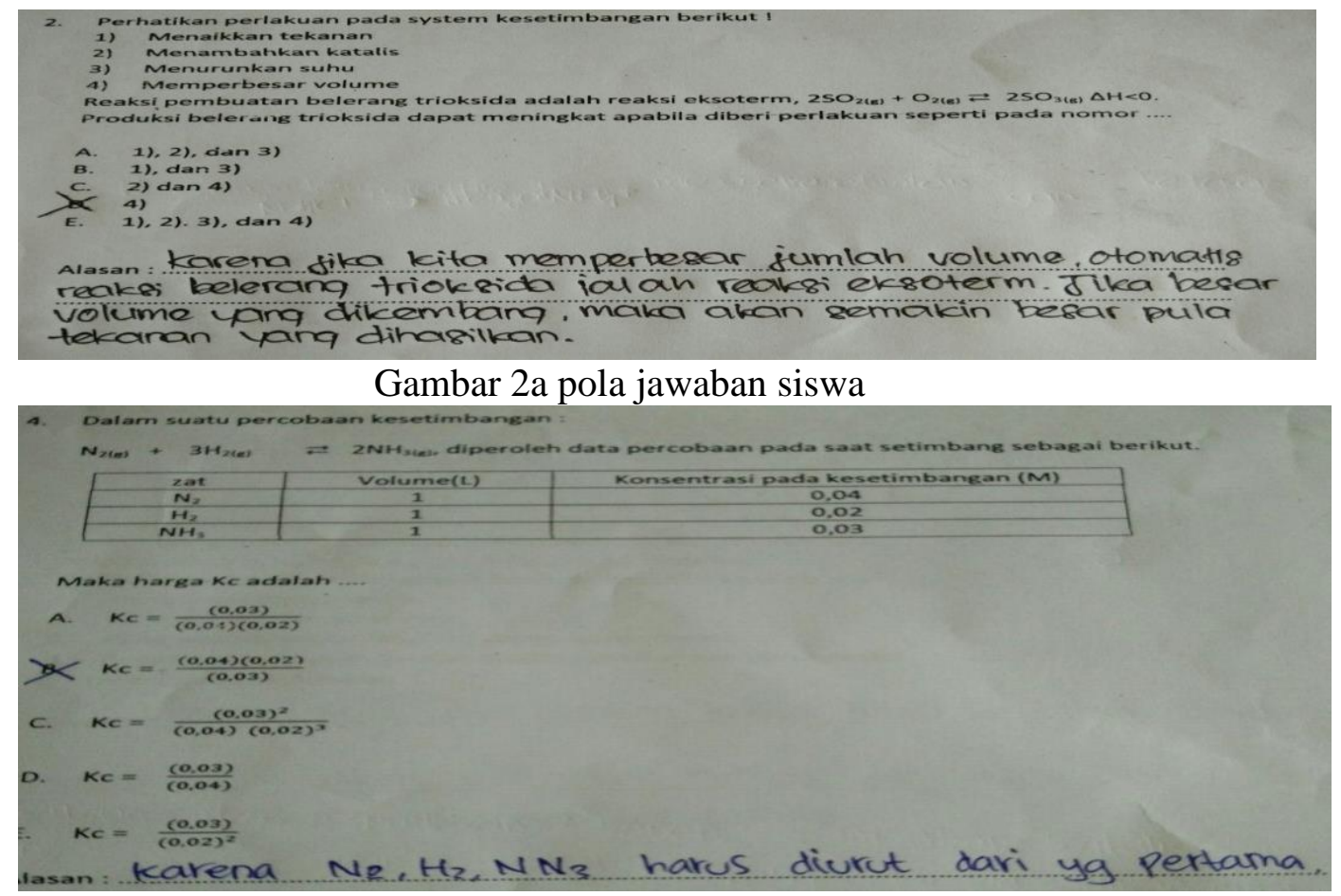

Gambar 2b. Pola jawaban siswa

(Hasil ulangan harian SMAN 5 Palangka Raya Tahun Ajaran 2016/2017)

Jawaban salah siswa gambar 2 dan 3 terlihat bahwa siswa beranggapan reaksi bergeser $\mathrm{ke} \mathrm{SO}_{3}$ adalah volume diperbesar. Selain itu tidak mampu menentukan tetapan kesetimbangan kimia $(\mathrm{Kc})$.

Berdasarkan uraian di atas perlu untuk dilakukan penelitian mengenai "Kesulitan memahami konseptual dan prosedural kesetimbangan kimia pada siswa SMA di Kota Palangka Raya”.

Penelitian ini bertujuan untuk mendeskripsikan kesulitan siswa kelas XI MIPA SMA Negeri dan Swasta di Kota Palangka Raya dalam memahami konseptual dan prosedural kesetimbangan kimia Tahun Ajaran 2017/2018. 


\section{PEMBAHASAN}

\section{A. Kesulitan dalam mempelajari ilmu kimia}

Menurut Arifin (1995), Kesulitan adalah ketidakberhasilan mencapai kualifikasi hasil belajar tertentu. Kesulitan siswa dalam mempelajari ilmu kimia dapat bersumber pada : (1) Kesulitan dalam memahami istilah. Kesulitan ini timbul karena kebanyakan siswa hanya hafal akan istilah dan tidak memahami dengan benar maksud dari istilah yang sering digunakan dalam pengajaran kimia; (2) Kesulitan dalam memahami konsep kimia. Kebanyakan konsep-konsep dalam ilmu kimia maupun materi kimia secara keseluruhan merupakan konsep atau materi yang bersifat abstrak dan kompeks, sehingga siswa dituntut untuk memahami konsep-konsep tersebut dengan benar dan mendalam; (3) Kesulitan angka.

Faktor-faktor yang menjadi penyebab kesulitan belajar antara lain banyak konsep kimia yang bersifat abstrak. Dalam mempelajari kimia siswa dihadapkan pada tiga level berpikir yaitu level makroskopik, mikroskopik dan lambang (representational). Tidak semua siswa dapat berpikir dengan baik pada level mikroskopik dan lambing. Untuk mempelajari kimia diperlukan kemampuan matematika yang memadai, di samping ada bagian-bagian yang memerlukan strategi menghafal.

Menurut Clement (dalam Weiner, 2003) kesulitan belajar merupakan kondisi dimana anak dengan kemampuan intelegensi rata-rata atau di atas rata-rata, namun memiliki ketidakmampuan atau kegagalan dalam belajar yang berkaitan dengan hambatan dalam proses persepsi, konseptualisasi, berbahasa, memori, pemusatan perhatian, penguasaan diri dan fungsi integrasi sensori motorik.

Pemahaman terhadap kata-kata kimia dapat menyebabkan saratnya beban memori siswa dan apabila kendala-kendala diatas tidak disadari maka siswa akan mengalami kesulitan mengasimilasi pengetahuan baru dalam rangka pembentukan konsep yang utuh. Pendapat ini diperkuat oleh Jhonstone \& Mac Gouire (1987) yang mengatakan bahwa penggunaa bahasa merupakan hal yang sangat penting karena banyak konsep-konsep sains (misalnya atom, molekul, elektron ) tidak dapat diamati secara langsung,oleh karena itu konsep-konsep tersebut sulit dimengerti tanpa ungkapan melalui bahasa.

B. Kesulitan Kesetimbangan Kimia

Penelitian yang berkaitan dengan kesulitan siswa dalam memahami konsep mikroskopik yang telah dilakukan adalah sebagai berikut. Maskil \& Helena (1977:101) mengemukakan bahwa siswa kesulitan memahami konsep partikel pada tingkat mikroskopis. Sihaloho (2001: 136) mengemukakan siswa maupun guru kesulitan memahami tentang proses yang terdapat dalam larutan. Penelitianpenelitian lain yang melaporkan tentang kesalahan siswa dalam memahami konsep-konsep pada tingkat mikroskopis antara lain adalah keadaan partikel asam basa (Nakheh, 1994: 495) dan siswa dan elektrokimia (Huddle, Margaret \& Rogers, 2000:104).

Sifat makroskopis pada kesetimbangan kimia adalah perubahan yang dapat dilihat atau diukur sedangkan sifat mikroskopis artinya secara molekuler terjadi reaksi pereaksi membentuk hasil reaksi, atau sebaliknya, terjadi reaksi antar hasil reaksi membentuk pereaksi dengan laju yang tepat sama. Tetapi tampilan parameter sistem secara keseluruhan tidak mengalami perubahan. 
Sifat lain dari kesetimbangan kimia adalah dapat didekati dari arah manapun. Karena keadaan kesetimbangan merupakan proses reversible, maka dapat meninjau system dari arah pereaksi atau dari arah hasil reaksi. Contoh,Jika $\mathrm{I}_{2(\mathrm{~g})}$, $\mathrm{H}_{2(\mathrm{~g})}$, dan $\mathrm{HI}_{(\mathrm{g})}$ dicampurkan, kita tidak dapat menentukan mana pereaksi dan mana hasil reaksi secara tegas sebagai reaksi kesetimbangan dapat didekati dari dua arah.

Konsep pergeseran kesetimbangan kimia merupakan salah satu materi esensial yang sebagian besar konsepnya bersifat abstrak. Pokok bahasan ini diajarkan pada siswa kelas XI semester 1. Keabstrakan konsep-konsep pada pokok bahasan ini sangat potensial dalam menimbulkan kesalahan konsep. Tujuan dari penelitian ini adalah untuk menjelaskan kesulitan siswa dalam memahami konseptual dan prosedural kesetimbangan kimia dari segi makroskopik dan mikroskopi siswa kelas XI SMA Kota Palangka Raya dalam bentuk gambar.

C. Kesetimbangan Dinamis

Pada umumnya reaksi-reaksi kimia tersebut berlangsung dalam arah bolakbalik (reversible), dan hanya sebagian kecil saja yang berlangsung satu arah. Pada awal proses bolak-balik, reaksi berlangsung kea rah pembentukan produk, segera setelah terbentuk molekul produk maka terjadi reaksi sebaliknya, yaitu pembentukan molekul reaktan dari molekul produk. Ketika lajureaksi ke kanan dan ke kiri sama dan konsentrasi reaktan dan produk tidak berubah maka kesetimbangan reaksi tercapai. Banyak reaksi tidak berkesudahan dan pada kondisi tertentu, konsentrasi pereaksi dan produk reaksi menjadi tetap. Reaksi yang demikian disebut reaksi reversible dan tercapai kesetimbangan (Sudyana, 2006). Contohnya pada reaksi kesetimbangan :

$\begin{array}{lcc}\mathrm{CuSO}_{4} .5 \mathrm{H}_{2} \mathrm{O} & \stackrel{\text { Laju reaksi ke kiri }}{\rightleftarrows} \\ \text { Reaktan } & \text { laju reaksi ke kanan } & \begin{array}{c}\mathrm{CuSO}_{4} \\ \text { produk }\end{array}\end{array}$

Pada reaksi semacam ini produk yang terjadi akan bereaksi membentuk kembali pereaksi. Ketika reaksi berlangsung laju reaksi ke depan (ke kanan), sedangkan laju reaksi sebaliknya ke belakang (ke kiri) bertambah, sebab konsentrasi pereaksi berkurang dan konsentrasi produk reaksi semakin bertambah. Pada umumnya suatu reaksi kimia yang berlangsung spontan akan terus berlangsung sampai dicapai keadaan kesetimbangan dinamis.

Keadaan kesetimbangan dikatakan dinamis bila keadaan kesetaraan laju reaksi maju dan laju reaksi maju dapat dipertahankan. Sebagai contoh, pada reaksi gas $\mathrm{H}_{2}$ dengan $\mathrm{I}_{2}$ menghasilkan gas $\mathrm{HI}$ yang berbentuk keadaan kesetimbangan.Sistem tersebut dikatakan setimbang dinamis, apa bila gas $\mathrm{H}_{2}$ denga $\mathrm{I}_{2}$ bereaksi secara berkesinambungan membentuk gas HI dan dilain pihak dalam system tersebut gas HI terurai secara berkesinambungan membentuk gas $\mathrm{H}_{2}$ dan $\mathrm{I}_{2}$ dengan laju yang sama.Hubungan laju reaksi zat dengan waktu pada kesetimbangan dinamis dari reaksi gas $\mathrm{H}_{2}$ dengan $\mathrm{I}_{2}$ membentuk gas HI atau sebaliknya dapat dinyatakan dalam bentuk grafik seperti yang ditunjukkan pada gambar berikut ini. 


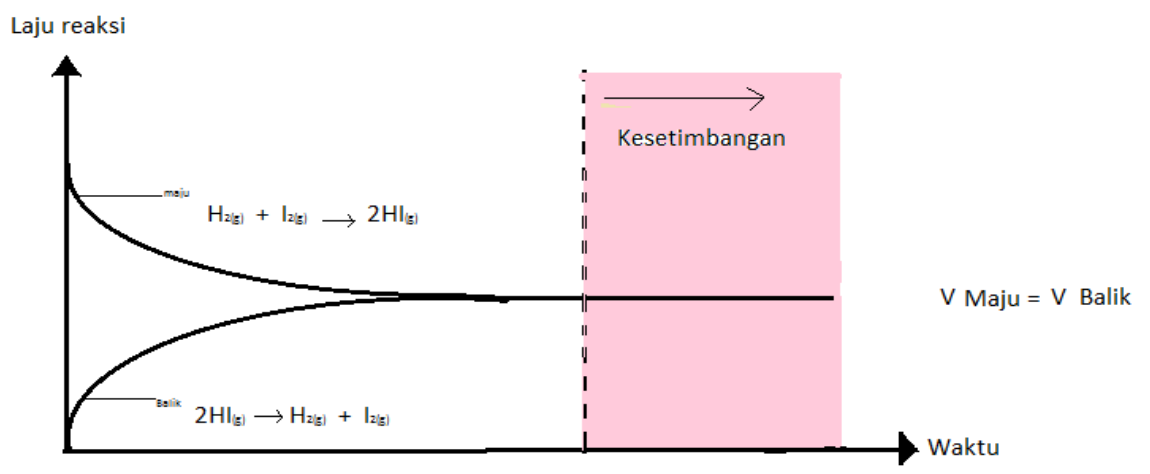

Gambar 3. grafik reaksi kesetimbangan $\mathrm{H}_{2}, \mathrm{I}_{2}$ dan $\mathrm{HI}$

\section{Pengaruh Perubahan Konsentrasi}

Perubahan konsentrasi dapat mempengaruhi kesetimbangan reaksi. Perubahan reaksi dapat dilakukan dengan cara menambahkan atau mengurangi konsentrasi pereaksi. Jika ke dalam system kesetimbangan konsentrasi pereaksi ditambah atau diperbesar, kesetimbangn bergeser ke kanan atau kearah produk, sehingga konsentrasi produk bertambah. Sebaliknya, jika konsentrasi pereaksi dikurangi atau diperkecil, kesetimbangan bergeser ke kiri atau kearah pereaksi bertambah.

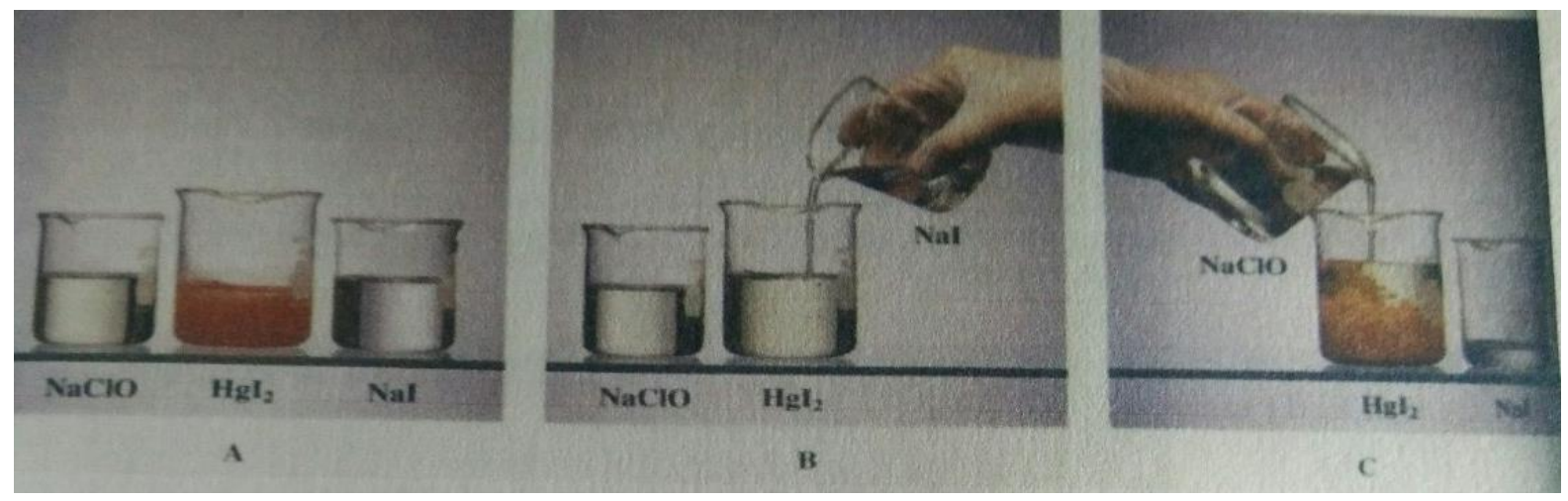

Gambar 4. Efek perubahan konsentrasi terhadap kesetimbangan kimia

Keterangan gambar :

A. gelas kimia yang berada di tengah mengandung endapan yang berwarna orange dari $\mathrm{HgI}_{2}$ dalam kesetimbangan $\mathrm{I}^{-}$(tidak berwarna) dan $\mathrm{HgI}_{4}{ }^{2-}$ (kuning pucat), reaksi :
$\mathrm{HgI}_{2(\mathrm{~s})}+2 \mathrm{I}_{(\mathrm{aq})}^{-}$
$\rightleftarrows \quad \mathrm{HgI}_{4}^{2-}(\mathrm{aq})$
Orange
kuning pucat

B. Larutan $\mathrm{NaI}$ (gelas kimia yang berada di sebelah kanan) ditambahkan ke dalam sistem kesetimbangan yang berada di tengah. Dengan menambahkan $\mathrm{I}_{(\mathrm{aq})}^{-}$, maka reaksi bergeser ke kanan. lenyap.

Reaksi : $\mathrm{HgI}_{2(\mathrm{~s})}+2 \mathrm{I}_{(\mathrm{aq})}^{-} \rightarrow \mathrm{HgI}_{4}{ }^{2-}{ }_{(\mathrm{aq})}$ warna orange endapan dari $\mathrm{HgI}_{2}$

$$
\text { Orange kuning pucat }
$$

C. larutan $\mathrm{NaClO}$ (gelas kimia yang berada di sebelah kiri/ $\mathrm{HgI}_{2}$ ), kemudian ditambahkan pada sistem kesetimbangan. $\mathrm{NaClO}$ mengubah $\mathrm{I}^{-}$dengan cara 
mengoksidasinya menjadi $\mathrm{IO}^{-}$. Dengan mengurangi I-, reaksi bergeser ke kiri.

Reaksi : $\mathrm{HgI}_{2(\mathrm{~s})}+2 \mathrm{I}_{(\mathrm{aq})}^{-} \rightarrow \mathrm{HgI}_{4}^{2-}{ }_{(\mathrm{aq})}$. Endapan $\mathrm{HgI}_{2}$ yang berwarna orange terjadi.

Dari contoh di atas kita dapat merumuskan pengaruh perubahan konsentrasi terhadap suatu kesetimbangan sebagai berikut :

a. jika salah satu zat konsentrasinya diperbesar maka kesetimbangan akan bergeser dari arah zat tersebut

b. jika salah satu zat konsentrasinya diperkecil maka kesetimbangan akan bergeser ke arah zat tersebut.

E. Pengaruh Perubahan Suhu

Pada reaksi kesetimbangn, apabila kalor sistem reaksi berkurang karena penurunan suhu dengan cara menurunkan suhu sistem tersebut (misal dengan memasukkan campuran reaksi kedalam air es), menurut prinsip Le Chatelier, sistem akan melakukan reaksi dengan cara menggeser kesetimbangan kearah yang menghasilkan kalor (eksoterm). Sebaliknya, jika kalor sistem meningkat, sistem akan bergeser ke arah yang memerlukan kalor (endoterm).

Contoh: $\mathrm{A}_{(\mathrm{g})}+\mathrm{B}_{(\mathrm{g})} \rightleftarrows \mathrm{C}_{(\mathrm{g})}+\mathrm{D}_{(\mathrm{g})} ; \Delta \mathrm{H}=-\mathrm{X} \mathrm{kJ}$

Reaksi 1 adalah eksoterm, yaitu zat A dan B membebaskan kalor untuk membentuk zat $\mathrm{C}$ dan D. Reaksi 2 adalah endoterm, yaitu zat $\mathrm{C}$ dan $\mathrm{D}$ menyerap kalor untuk membentuk zat A dan B. Jika pada sistem kesetimbangan tersebut suhu dinaikkan, kesetimbangan akan bergeser ke kiri atau ke arah endoterm. Sebaliknya, jika dalam sistem kesetimbangan tersebut suhu diturunkan kesetimbangan akan bergeser ke eksoterm.

Contoh lain reaksi pengaruh suhu terhadap kesetimbangan :

$$
\mathrm{Co}\left(\mathrm{H}_{2} \mathrm{O}\right)_{6}{ }^{2+}{ }_{(\mathrm{aq})}+4 \mathrm{Cl}^{-}{ }_{\text {(aq) }} \rightleftarrows \mathrm{CoCl}_{4}{ }^{2-}{ }_{(\mathrm{aq})}+6 \mathrm{H}_{2} \mathrm{O}_{(\mathrm{l})} ; \Delta \mathrm{H}=+\mathrm{kJ}
$$
Pink

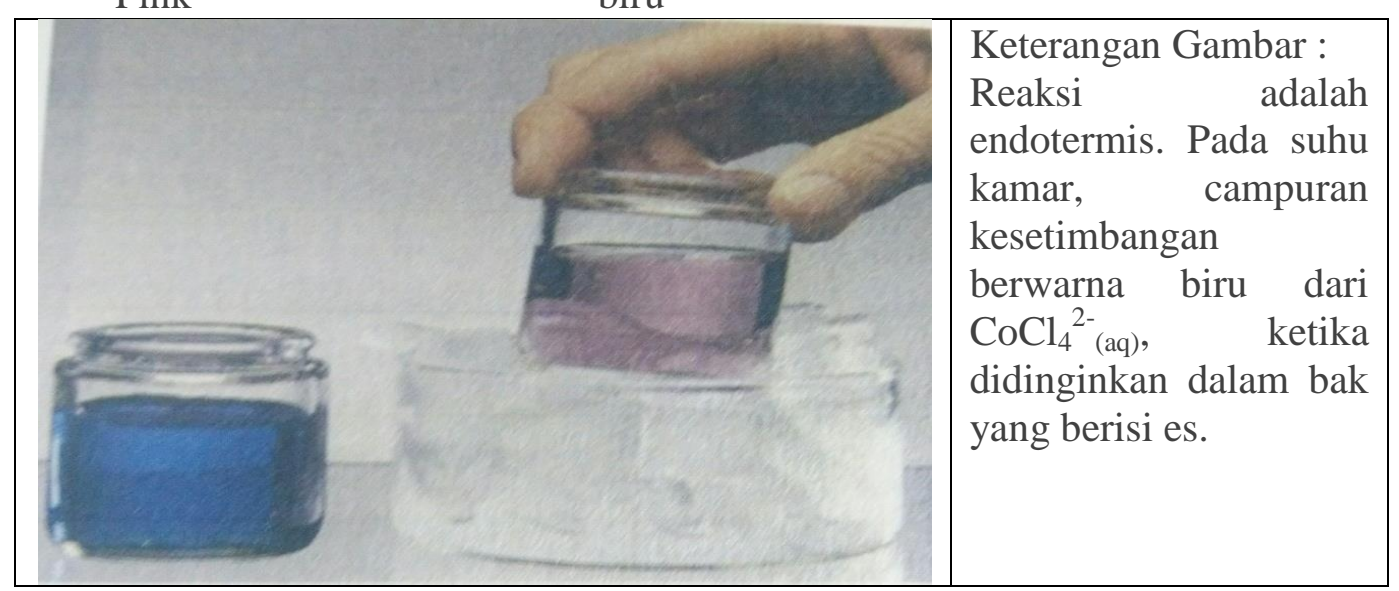

Gambar 5. Efek perubahan suhu terhadap kesetimbangan

Dari contoh di atas, pengaruh suhu terhadap pergeseran kesetimbangan reaksi eksoterm dapat diringkas sebagai berikut :

a. Jika suhu reaksi dinaikkan, reaksi akan bergeser ke arah pereaksi

b. jika suhu diturunkan, reaksi akan bergeser ke arah hasil reaksi.

F. Pengaruh Perubahan Tekanan dan Volume

Pengaruh tekanan terhadap kesetimbangan reaksi hanya untuk sistem reaksi yang melibatkan gas.Faktor tekanan dan volume merupakan faktor yang bersifat kebalikan satu sama lain, artinya bila tekanan gas diperbesar, berarti volume gas 
diperkecil. Dan bila tekanan gas diperkecil, berarti volume gas diperbesar. Hal ini sesuai dengan hukum Boyle yang menyatakan bahwa paa suhu tetap, hasil kali tekanan $(\mathrm{P})$ dan volume $(\mathrm{V})$ selalu konstan $(\mathrm{P} . \mathrm{V}=\mathrm{C})$.

Menurut asas Le Chatelier, "jika dalam sistem kesetimbangan volume ruang diperbesar atau tekanan diperkecil maka kesetimbangan akan bergeser ke pihak reaksi yang jumlah koefisiennya lebih besar. Sebaliknya jika dalam sistem kesetimbangan volume ruang diperkecil (tekanan diperbesar), kesetimbagan akan bergeser kepihak reaksi yang jumlah koefisiennya lebih kecil”.

Contoh : $2 \mathrm{~A}_{(\mathrm{g})}+\mathrm{B}_{(\mathrm{g})} \underset{\mathrm{V} 2}{\stackrel{\mathrm{V} 1}{\rightleftarrows}} 3 \mathrm{C}_{(\mathrm{g})}+\mathrm{D}_{(\mathrm{g})}$

Jika pada suhu tetap volume ruang diperbesar (tekanan diperkecil), kesetimbangan akan bergeser ke kanan (ke jumlah koefisien besar). Sebaliknya, jika volume diperkecil (tekanan diperbesar) kesetimbangan akan bergeser ke kiri (ke jumlah koefisien kecil).

Apabila dalam sistem kesetimbangan jumlah koefisien reaksi antara ruas kanan dan kiri sama maka perubahan tekanan dan volume tidak mempengaruhi letak kesetimbangan.

Contoh: $\mathrm{H}_{2(\mathrm{~g})}+\mathrm{I}_{2(\mathrm{~g})} \rightleftarrows 2 \mathrm{HI}(\mathrm{g})$

$$
\mathrm{N}_{2(\mathrm{~g})}+\mathrm{O}_{2(\mathrm{~g})} \rightleftarrows 2 \mathrm{NO}_{(\mathrm{g})}
$$

Pada reaksi tersebut,meskipun pada reaktan tekanan diperbesar atau diperkecil, kesetimbangan reaksi tidak akan bergeser karena koefisien reaksi antara reaktan dan produk sama. Untuk reaksi

$\mathrm{aA}+\mathrm{bB} \rightleftarrows \mathrm{cC}+\mathrm{dD}$

Perubahan tekanan hanya akan menggeser kesetimbangan apabila

Total Mol Pereaksi $\neq$ Total Mol Produk reaksi.

$$
(\mathrm{a}+\mathrm{b}) \quad(\mathrm{c}+\mathrm{d})
$$

- Jika tekanan bertambah (konsentrasi zat-zat bertambah), kesetimbangan akan bergeser dengan total mol lebih sedikit untuk menurunkan tekanan (konsentrasi zat-zat) sampai kesetimbangan baru dicapai.

- Jika tekanan berkurang (konsentrasi zat-zat berkurang), kesetimbangan akan bergeser ke arah dengan total mol lebih banyak untuk menaikkan tekanan (konsentrasi zat-zat) sampai kesetimbangan baru dicapai.

Pada sistem kesetimbangan heterogen, pengaruh tekanan dan volume pada pergeseran kesetimbangan tidak dipengaruhi oleh zat padat atau zat ciar, tetapi hanya dipengaruhi oleh komponen berwujud gas.

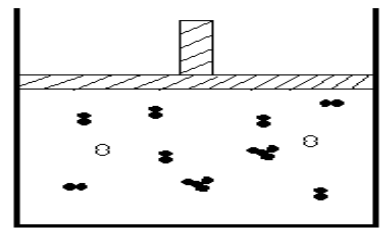

Kesetimbangan

Gambar

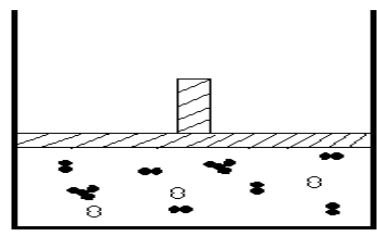

Volume diubah

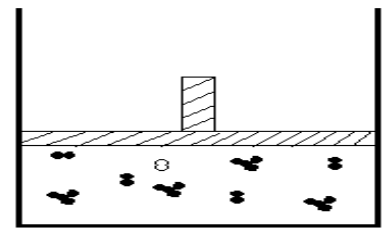

Kesetimbangan baru

kesetimbangan kimia

Keterangan Gambar :

6. Efek Perubahan

Tekanan/Volume terhadap

$\boldsymbol{\vartheta}=\mathrm{NH}_{3}$

A. Sistem kesetimbangan dari molekul-molekul $\mathrm{N}_{2}, \mathrm{H}_{2}$, dan $\mathrm{NH}_{3}$. 
B. Campuran gas tersebut ditekan sampai volumennya menjadi $1 / 2$ dari volume semula, meningkatkan tekanan parsial, sehingga campuran tersebut tidak lagi dalam keadaan setimbang.

C. Kesetimbangan kembali tercapai, ketika reaksi bergerak maju $\mathrm{N} 2\left(_{\mathrm{g})}+\right.$ $3 \mathrm{H}_{2(\mathrm{~g})} \rightarrow 2 \mathrm{NH}_{3(\mathrm{~g})}$

Dari gambar konseptual ini, dapat disimpulkan bila tekanan ditambah, maka sebagian molekul $\mathrm{N}_{2}$ akan bereaksi dengan molekul $\mathrm{H}_{2}$ membentuk molekul pada sistem kesetimbangan baru. Pengaruh tekanan dan volume terhadap pergeseran kesetimbangan dapat diringkas sebagai berikut :

a. Jika tekanan diperbesar (volume diperkecil) maka kesetimbangan akan bergeser ke arah jumlah mol yang lebih kecil.

b. Jika tekanan diperkecil (volume diperbesar) maka kesetimbangan akan bergeser ke arah jumlah mol yang lebih besar.

G. Pengaruh Katalisator

Dalam semua reaksi kimia penurunan energi aktivasi akan mempercepat terjadi reaksi. Penurunan energi aktivasi berlaku untk ke dua arah. Jadi katalisator akan mempercepat lajureaksi maju sekaligus reaksi balik. Oleh sebab itu, pengunaan katalisator akan mempercepat tercapainya keadaan setimbang. Berikut ini gambar pengaruh katalisator terhadap pencapaian kesetimbangan.

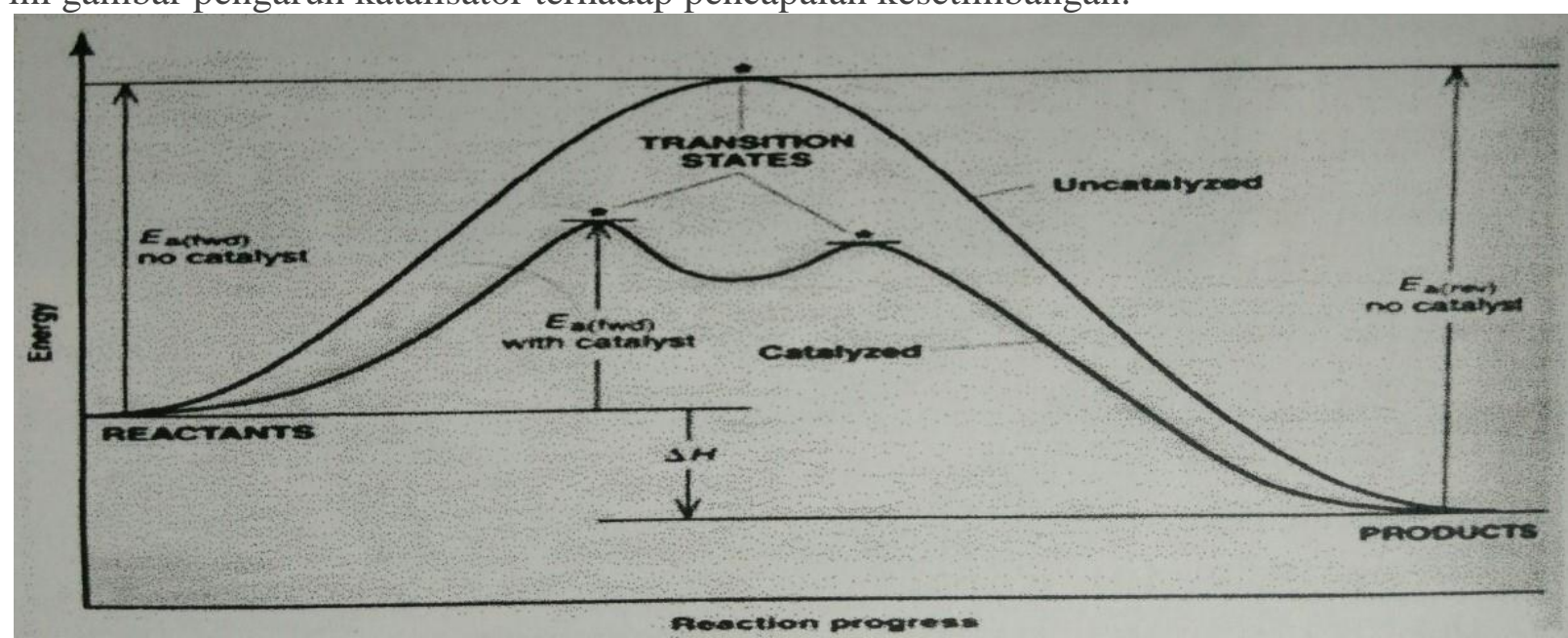

Gambar 9. Proses Pencapaian Kesetimbangan dengan dan tanpa katalisator

Meskipun katalisator dapat mempercepat pencapaian keadaan setimbang, namun katalisator tidak mengubah komposisi kesetimbangan.

\section{KESIMPULAN}

Berdasarkan pembahasan dapat disimpulkan bahwa siswa-siswi SMA di kota Palangka Raya mengalami kesulitan dalam konseptual dan prosedural (1) kesetimbangan dinamis; (2) pengaruh perubahan suhu terhadap pergeseran kesetimbangan (3) Pengaruh perubahan konsentrasi terhadap pergeseran kesetimbangan;(4) Pengaruh perubahan volume dan tekanan pada pergeseran kesetimbangan.

Penyebab kesulitan adalah siswa tidak mengerti konsep yang bersifat makrokopis dan mikrokopis. Sifat makrokopis pada kesetimbangan kimia adalah perubahan yang dapat dilihat dan diukur sedangkan sifat mikroskopis artinya secara molekuler terjadi reaksi pereaksi membentuk hasil reaksi, atau sebaliknya, terjadi reaksi antar hasil reaksi membentuk pereaksi dengan laju yang sama. 
Tetapi tampilan parameter sistem secara keseluruhan tidak mengalami perubahan. Konsep mikrokopis dapat menimbulkan pemahaman yang salah, yang mana apabila pemahaman yang salah berlangsung secara konsisten akan menimbulkan terjadinya salah konsep.

Guru menjelaskan materi kesetimbangan kimia dalam bentuk gambar, sehingga siswa mengerti arti gambar tersebut terkait dengan reaksi kesetimbangan kimia.

\section{DAFTAR PU5TAKA}

Arifin, Mulyati.1994. Pengembangan Program Pengajaran Bidang studi Kimia. Bandung : Airlangga University Press.

Anas Sudijono. 2006. Pengantar Evaluasi Pendidikan. Jakarta : PT. Raja Grafindo Persada.

Andrie, Yunitha. 2012. Kesulitan Memahami Konsep Kesetimbangan Kimia Pada Siswa Kelas XI SMAN Tahun Ajaran 2011/2012 Di Kota Palangka Raya. Palangka Raya : Unpar.

Commy,R.B. 1999. Pendidikan Tinggi : Peningkatan Kemampuan Manusia Sepanjang Hayat Seoptimal Mungkin. Jakarta : PT. Grasido

Depdiknas, 2013. Silabus Kurikulum 2013 kimia SMA. Jakarta : Direktorat Pembinaan SMA.

Ekawati, Yuli. 2016. Kesulitan Memahami Konsep Larutan Penyangga Pada Siswa Di SMA Negeri Kabupaten Pulang Pisau dan Kota Palangka Raya.Tesis tidak diterbitkan. Palangka Raya : UPR.

Hayati, siti. 2016. Kesulitan Siswa Memahami Pereaksi Pembatas Di SMA

Kabupaten Barito Utara dan Kota Palangka Raya Tahun Pelajaran

2015/2016. Tesis tidak diterbitkan. Palangka Raya : UPR.

Jeren, I K. 1998. Keberhasilan Siswa Kelas II SMU Panatiring Tangkiling Menyelesaikan Soal-Soal Hitungan Kesetimbangan Kimia Tahun

Pelajaran 1997/1998. Skripsi tidak diterbitkan. Palangka Raya : Unpar.

Nendiyati. 2016. Kesulitan Memahami Hukum Perbandingan Volume dan Hukum Avogadro Pada Siswa SMAN Di Palangka Raya dan Muara Teweh. Tesis tidak diterbitkan. Palangka Raya : UPR.

Pangganti, Esdi. 2001. Kesalahan Konsep Siswa Kelas II Catur Wulan 2 SMUN-1 Muara Teweh Tahun Ajaran 2000/2001 Dalam Menentukan arah Pergeseran Kesetimbangan Kimia akibat Perubahan Konsentrasi Berdasarkan Prinsip Le Chaterier. Skripsi tidak diterbitkan. Palangka Raya : Unpar

Sidauruk, Suandi. 1995. Kesulitan Siswa SMA Memahami Konsep-Konsep Ilmu Kimia. Tesis tidak diterbitkan. Jakarta : IKIP

Sudyana, A. 1995. Pengaruh Model Pembelajaran Melalui Seting Belajar

Kooperatif Terhadap Pemahaman Konseptual dan Pemahaman S Algoritmik Kimia Siswa SMA. Desertasi tidak diterbitkan. Malang : Universitas Negeri Malang. 